\title{
A Rule-Based Medium-Term Fiscal \\ Policy Framework for Tanzania
}

\author{
Daehaeng Kim and Mika Saito
}




\title{
IMF Working Paper
}

\author{
African Department \\ A Rule-Based Medium-Term Fiscal Policy Framework for Tanzania
}

Prepared by Daehaeng Kim and Mika Saito

Authorized for distribution by David O. Robinson

November 2009

\begin{abstract}

\section{This Working Paper should not be reported as representing the views of the IMF.} The views expressed in this Working Paper are those of the authors and do not necessarily represent those of the IMF or IMF policy or the country authorities. Working Papers describe research in progress by the authors and are published to elicit comments and to further debate.
\end{abstract}

A zero net domestic financing (NDF) target has served Tanzania well in recent years, contributing to prudent expenditure policy, improved fiscal sustainability, and macroeconomic stability. Moving to a more flexible fiscal policy, however, may serve Tanzania better. The "diamond rule" proposed in this paper incorporates a permanent hard ceiling on debt and annual benchmark limits on NDF, expenditure growth, and nonconcessional external financing. This rule would provide flexibility for countercyclical policy and help define the fiscal space for infrastructure spending that is consistent with longrun fiscal sustainability. An illustrative simulation shows that Tanzania has considerable fiscal space for development spending.

JEL Classification Numbers:H50, H54, H60, H63

Keywords: Fiscal sustainability, fiscal rules, medium-term fiscal framework

Author’s E-Mail Address:ㅆkim2@imf.org and msaito@imf.org 


\section{Contents}

Executive Summary

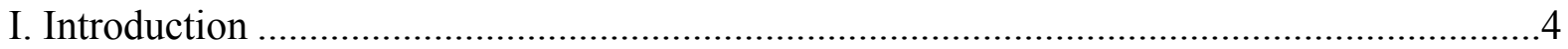

II. Fiscal Policy in Tanzania: Improvements and Vulnerabilities.....................................6

III. A Rule-Based Medium-Term Fiscal Policy............................................................. 8

IV. A Possible Medium-Term Fiscal Policy Framework for Tanzania ................................16

V. Application of the Proposed Diamond Rule to Tanzania ..............................................19

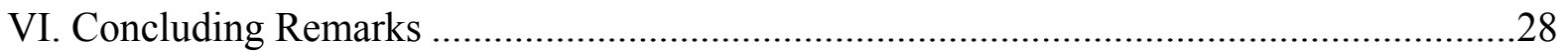

Tables

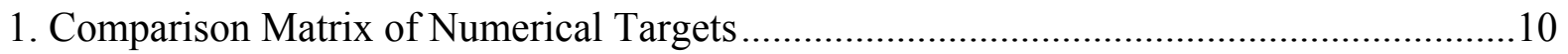

2. Fiscal Rules in Selected Economies ........................................................................ 11

3. Fiscal Rules in Sub-Saharan African Countries............................................................. 13

Figures

1. Government Domestic Revenue and GDP per Capita in Selected .........................6

2. Indicators of Public Debt, 2008-2028 Baseline .............................................................22

3. Indicators of Public Debt, 2008-2028 Alternative Scenario ..........................................26

4. Indicators of Public Debt, 2008-2028 Role of Concessional Borrowing and Grants .........27

Boxes

1. Fiscal Risks Disclosure .......................................................................................

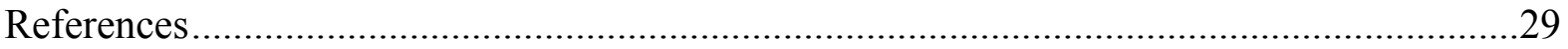




\section{Executive Summary}

Tanzania's fiscal policy in recent years has been guided by a zero net domestic financing (NDF) ceiling. It has supported prudent expenditure policy, which together with strong revenue performance has contributed to fiscal sustainability and economic stability. However, there are several reasons why Tanzania might consider shifting to a rule-based medium-term policy framework. That could (i) provide more flexibility for countercyclical policy; (ii) help define the fiscal space available for more infrastructure spending consistent with fiscal sustainability; and (iii) facilitate regional convergence and economic integration. A rules-based approach would reinforce the credibility of Tanzania's commitment to sound fiscal policies.

A fiscal policy rule is generally defined as a mechanism that places durable constraints on fiscal discretion through numerical limits on budgetary aggregates. In practice, fiscal policy is typically anchored on (i) budget balances or their cyclical variants; (ii) all or specific categories of spending; (iii) revenue or the tax rate; and (iv) public debt. The design of a policy rule faces important trade-offs between targets and varies widely, reflecting countryspecific circumstances and policy priorities. To minimize the credibility-flexibility trade-off, in practice combinations of targets are often used, but it is important to keep the rule operationally simple and transparent.

In Tanzania the importance of avoiding reaccumulation of unsustainable public debt suggests that medium-term fiscal policy could be guided by a "diamond rule" consisting of a fiscal anchor and three complementary benchmarks.

The recommended primary medium-term anchor is the present value (PV) of gross public debt. In line with a cross-section of emerging market economies, a desirable ceiling for the PV of public debt-to-GDP ratio for Tanzania might be 40 percent of GDP. Beyond this amount, excessive borrowing and the resulting high interest payments would limit other essential spending. Within this debt ceiling, three benchmarks would serve to prevent too rapid a buildup of fiscal vulnerabilities: (i) a limit on net domestic financing in a single year (say, 21/2 percent of GDP); (ii) a limit on nonconcessional external borrowing (also $2 \frac{1}{2}$ percent of GDP); and (iii) a limit on the change in the ratio of spending to GDP (say, 3 percentage points of GDP).

An illustrative simulation shows that stepping up development spending by 2 percentage points of GDP from the current level for 5 years would be consistent with the diamond rule based on reasonable assumptions about growth, inflation, financing costs, and the growthenhancing effect of infrastructure investment. However, the simulation also confirms that ensuring that public investment does enhance growth and that there is access to low-cost financing are critical to keep Tanzania's debt sustainable. Thus Tanzania needs to continue to explore low-cost financing for infrastructure investment, and fine-tune expenditure policy to maximize the growth impact of that investment, giving particular attention to project selection, execution, and monitoring. 


\section{INTRODUCTION}

Over the past decade, Tanzania has sustained high rates of economic growth. Prudent expenditure policy and strong revenue performance have helped ensure both fiscal sustainability and economic stability - key ingredients for growth. Thanks to debt relief from the HIPC and MDRI initiatives, strong economic growth, and improved management of public finances, Tanzania's external public debt has fallen from about 90 percent of GDP in the late 1990s to 21 percent in 2007/08. With domestic debt at about 141/4 percent of GDP, total public debt was just over 35 percent of GDP at the end of 2007/08. The present value (PV) of total public debt was considerably lower (251/2 percent of GDP), due to the high share of concessional borrowing.

Under the authorities' programs supported by the Fund, the government net domestic financing (NDF) target has served well as Tanzania's fiscal anchor. In recent years, budget preparation has been subject to a "zero NDF" rule: any after-grant budget deficit was to be financed entirely by concessional foreign financing. The discipline this rule exerted not only helped Tanzania to reduce its public debt but also eased inflation pressures and avoided crowding out credit to the private sector, which grew rapidly. However, the zero NDF rule has some shortcomings: (i) it could be procyclical, especially during economic downturns; ${ }^{1}$ and (ii) it lacks a medium-term perspective that could accommodate growth-enhancing public investment, for example in infrastructure.

Because these shortcomings could outweigh the short-term benefits of ensuring fiscal discipline, there is increasing need for Tanzania to consider shifting from annual NDF targeting to a rule-based medium-term fiscal policy framework (MTFPF). An MTFPF could (i) provide more flexibility for countercyclical policy; (ii) help define the fiscal space available for more infrastructure spending; ${ }^{2}$ and (iii) facilitate regional convergence and economic integration (e.g., the East African Community [EAC] monetary union). In the current budget process, relaxation of the zero NDF policy could generate uncertainty about the authorities' commitment to macroeconomic stability - notably keeping inflation lowwhereas an explicit MTFPF could help properly assess the impact of a near-term relaxation of the fiscal stance.

Indeed, given Tanzania's low level of public debt, an explicit MTFPF would reveal that there is considerable fiscal space that could allow a prolonged loosening of the current fiscal stance for productive public investment. Lack of adequate infrastructure is generally recognized as a major constraint on Tanzania's social welfare and economic growth. To address the problem, the Tanzanian government plans to accelerate public investment. Various options for mobilizing additional resources to support such a stepping up of investment spending have

\footnotetext{
${ }^{1}$ In principle, NDF targeting can be flexible. For example, during an economic downturn parliament could approve a more relaxed supplementary budget. However, this is more cumbersome than starting the year with some flexibility.

${ }^{2}$ Heller (2005) defines fiscal space as budgetary room that allows a government to provide resources for a desired purpose without any prejudice to the sustainability of a government's financial position.
} 
been explored by the authorities (Ter-Minassian, Hughes, and Hajdenberg, 2008), such as collecting more domestic revenue, reprioritizing spending, public-private partnerships (PPPs), external grants and concessional financing, and borrowing from international capital markets. Going forward with economic development strategies, rule-based fiscal policy could ensure that the annual fiscal position is consistent with economic stability, fiscal sustainability, and long-term economic growth.

Tanzania has been implementing a medium-term expenditure framework (MTEF) for a number of years. While the MTEF could offer useful guidance for the MTFPF, it has several weaknesses that make it difficult to realize its full benefits. Currently, mechanisms for discussing the MTEF within the government and with donors are established, and the MTEF is quantified, with targets for revenues, expenditures, and the deficit. However, because it is poorly aligned with both the annual budget process ${ }^{3}$ and the strategic budget allocation system, the MTEF cannot help position the annual budget in terms of the medium-term perspective. Moreover, the lack of focus on expenditure ceilings in Tanzania's MTEF and limited political ownership make it difficult to ensure that both medium-term planning and the annual budget are prepared using a consistent set of resource constraints. ${ }^{4}$

In this regard, a fiscal rule could guide both the MTEF and annual budget preparation. By imposing reasonable resource constraints for both the MTEF and the annual budget, the fiscal rule can bring them together, which will improve the consistency between medium-term planning and annual budgets. The rule can also be designed to take directly into account the fiscal sustainability issues, which are not always explicit in the MTEF, given the importance of avoiding reaccumulation of unsustainable public debt.

The growing popularity and generally positive experience with numerical fiscal rules suggest that one could be of value to Tanzania as well. Fiscal rules can help keep public finances on a sustainable path by constraining borrowing that exceeds debt servicing capacity, smooth output fluctuation, and create a budgetary cushion against adverse shocks and long-term fiscal pressures. ${ }^{5}$ It could be argued that as Tanzania begins to tap international capital markets, market discipline would ensure that fiscal policy remains sound. However, market discipline often comes too late, requiring sudden sharp adjustments; a well-designed fiscal rule could provide a useful complement to market discipline.

This paper focuses on key issues related to a medium-term fiscal policy anchor for Tanzania and, drawing on experiences in other countries, presents a range of suggestions for the government's consideration. Section II reviews Tanzania's fiscal policy in recent years and identifies risks that should be taken into account in designing a fiscal rule. Section III discusses fiscal rules in detail and international experience with them. Section IV presents

\footnotetext{
${ }^{3}$ Next-year MTEF estimates, which are usually made before the budget discussions, are not systematically used as the starting point for next-year budget preparation. This is true at both the aggregate and sectoral levels.

${ }^{4}$ In part, motivation for the MTEF in Tanzania is weak. As in many other African countries, international donors initiated the adoption of the MTEF in Tanzania.

${ }^{5}$ Output volatility adversely affects welfare, especially in low-income countries. Most empirical studies also find an inverse relationship between GDP volatility and long-term growth.
} 
specific suggestions to stimulate debate on the potential of numerical rules in Tanzania. Numerical simulations with various scenarios relevant for Tanzania are conducted in Section V. Section VI offers conclusions.

\section{Fiscal Policy in TANZania: Improvements AND Vulnerabilities}

Tanzania has made impressive progress in boosting tax revenues in recent years. With a broad tax base and a limited number of taxes, efforts to reinforce revenue administration have helped push up domestic revenues from 11 percent of GDP in 2002/03 to 16 percent in 2007/08. The contribution of Tanzania's Large Tax Department (LTD) has been particularly notable, and the Tanzanian Revenue Authority's latest corporate business plan aims to bring domestic revenue collection to 20 percent of GDP over the medium term.

With the recent improvements, domestic revenue mobilization in Tanzania is now in line with comparable countries (Figure 1). The performance of its LTD has also set a benchmark for similar units being established elsewhere in the region. However, there is still room to enhance domestic tax revenues through improvements in tax policy and administration. Revenue gains are expected to come from further capacity enhancement of the LTD and then adopting best practices for dealing with medium-sized taxpayers. Reforms to the fiscal regime for the mining sector currently under study also hold the prospect of revenue gains in the medium term (Ter-Minassian, Hughes, and Hajdenberg, 2008).

\section{Figure 1. Government Domestic Revenue and GDP per Capita in Selected African Countries (2008)}

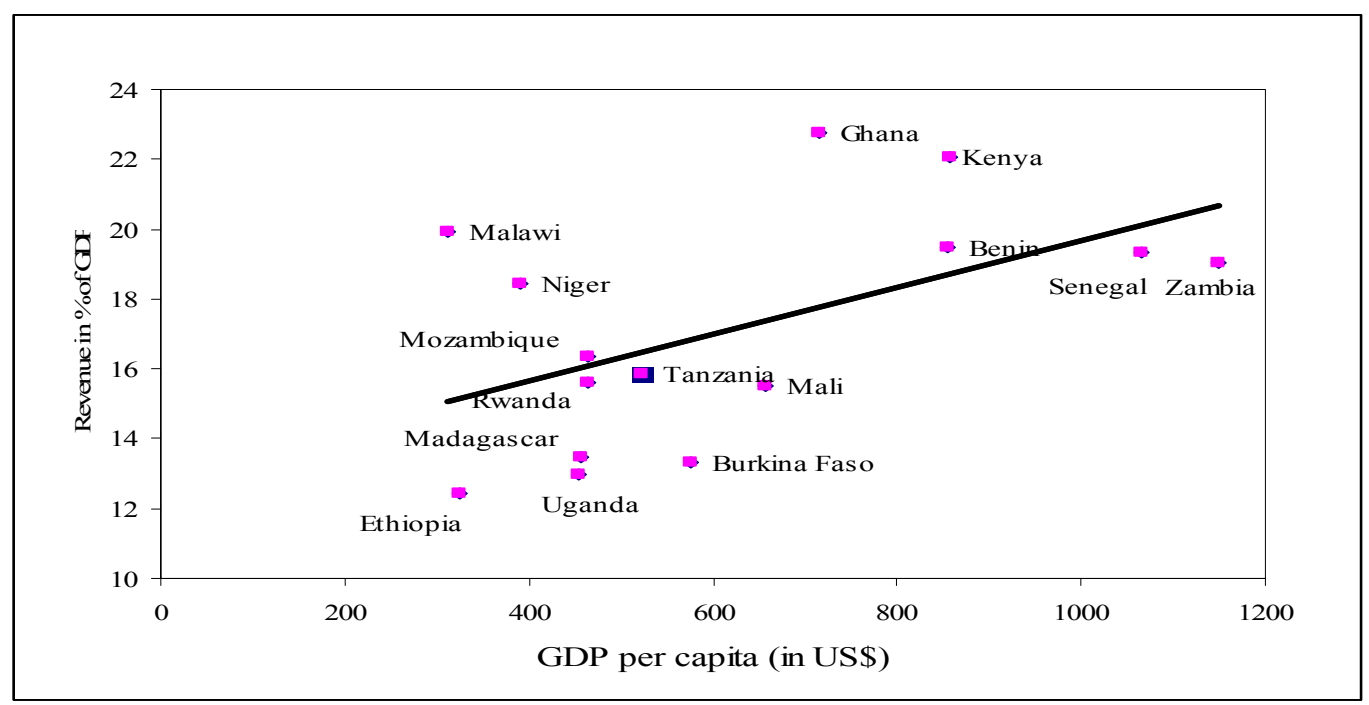

Source: IMF, World Economic Outlook.

With the sustained improvement in domestic revenue collection, prudent expenditure policy, which generally held annual public spending at about 23 percent of GDP for 2005-08, has reduced the fiscal deficit. However, encouraged by the improved debt situation due to the 
MDRI, ${ }^{6}$ as well as by recent revenue performance, the 2008/09 budget called for significantly higher expenditure in most categories, raising public expenditures by almost 40 percent relative to $2007 / 08$. The authorities' plan to step up infrastructure spending over the medium term, financed in part by issuing sovereign bonds, would further relax the expenditure policy.

\section{Box 1. Fiscal Risks Disclosure}

Fiscal risks could arise from a variety of sources, including macroeconomic shocks and the realization of contingent liabilities. These risks could undermine both the credibility of fiscal policy and confidence in fiscal sustainability, and there could be large fiscal costs should the risks materialize. For this reason many countries have made substantial efforts to effectively manage fiscal risks, and an increasing number of countries have recognized the benefits of transparent disclosure of these risks.

Greater transparency about fiscal risks generally strengthens the incentive to ensure that all risks are identified, estimated, and carefully managed. This could promote timely policy responses, increase the confidence of stakeholders in fiscal management, and reduce uncertainty for investors and taxpayers. Further, there is evidence that greater disclosure of fiscal risks improves access to international capital markets and reduces borrowing costs.

Many countries disclose risks associated with macroeconomic shocks. All EU countries, most OECD members, and some emerging market economies (e.g., Brazil, Chile, Indonesia) disclose risks associated with such macroeconomic assumptions as growth, inflation, interest rates, exchange rates, and international oil prices through sensitivity analyses, alternative macroeconomic scenarios, or stress tests for fiscal aggregates.

Often information on contingent liabilities (CLs) — especially loan guarantees - is also disclosed, though the extent of disclosure varies. The information is disclosed in a variety of venues, among them financial statements, budget documentation, medium-term fiscal frameworks, debt management reports, fiscal risk statements, and stand-alone CL reports. About 60 percent of the countries that disclose CLs present the information to the legislature. The disclosure statement generally classifies CLs by major category, fiscal significance, and rationale for taking on CLs, and details their nature, scope, and quantification (where possible).

This exercise requires both technical capacity and clear allocation of responsibilities to various parts of the public sector in assessing and reporting fiscal risks. For Tanzania, it might be practical to start with disclosing key risks, focusing on transparent reporting of information on public enterprises. The fiscal risk statement could be presented to parliament as an annex to the budget document; it should include a list of public enterprises, past and current transfers and guarantees, and summary information on public enterprise balance sheets. As experience with such an exercise builds up, the coverage and analysis should be improved, with subsequent statements highlighting changes in items reported since the previous statement.

\footnotetext{
${ }^{6}$ MDRI relief reduced total debt by US $\$ 4.9$ billion (including HIPC), or 60 percent of external debt as of end2005. The authorities are using the fiscal space for high-priority, proper social outlays and growth-critical economic projects.
} 
Despite recent improvements in public finances and debt sustainability, important fiscal risks remain in Tanzania (Box 1). ${ }^{7}$ Recent worsening of global economic and financial conditions could limit, or even unwind, further improvements in domestic revenue collection and the prospect for affordable commercial borrowing to finance higher public investment. In addition to the financing-side risks of relaxing the expenditure policy, however, there is ample evidence from international experience that increased investment spending does not always help realize the growth potential of an economy. ${ }^{8}$ While well-designed investment projects with high return should generate higher growth, financing projects that are less efficient would increase indebtedness without promoting growth, which would eventually cause an adverse market reaction and increase borrowing costs.

Fiscal risks could arise from contingent liabilities (CLs). Current CLs and their further buildup, while providing short-term support for the private sector ${ }^{9}$ and implementing public investment projects through public-private partnerships (PPPs) and large parastatals, ${ }^{10}$ should also be closely monitored and disclosed transparently. This would improve public confidence that Tanzania's fiscal risks are adequately managed. Given the fiscal challenges and risks ahead, a rule-based MTFPF would provide useful comprehensive policy support for Tanzania's economic policy and development strategies.

\section{A Rule-Based Medium-Term Fiscal Policy}

An increasing number of advanced and emerging market economies have introduced some type of fiscal rule to address deficit bias and procyclicality, which are well-known problems for fiscal policy. A degree of policy discretion is in principle desirable, since it provides flexibility to respond promptly to economic shocks. However, unconstrained discretionary choices may involve "wrong" incentives due to political economy factors (e.g., common pool problems, time inconsistency of governments, etc.); poor fiscal management; and off-budget fiscal activities. Further, lags in the formation and implementation of discretionary policy and financing constraints during downturns often lead to procyclical policy. In this regard, fiscal rules can help avoid misuse of discretion and promote fiscal discipline by placing durable constraints on fiscal discretion. Typical benefits from adopting fiscal rules are (i) economic stability, from enhanced fiscal policy credibility; (ii) long-term sustainability, from reduced deficit bias; and (iii) improved policy coordination between monetary and fiscal policies in an economy or within currency unions.

\footnotetext{
${ }^{7}$ Fiscal risks are broadly defined as short- to medium-term variations in the level of government expenditure, revenue, assets, and (both explicit and implicit) liabilities that are not fully anticipated in budget estimates.

${ }^{8}$ In particular, increased infrastructure spending in Tanzania does not always seem to have translated into improvements in the quality of and access to infrastructure services. For details, see Ndulu (2006) and Briceno and Foster (2007).

${ }^{9}$ In preparing the $2009 / 10$ budget, the authorities consider providing loan guarantees for cash crop traders, who suffered significant losses due to falling prices in 2009.

${ }^{10}$ PPPs and investment by parastatal enterprises are often used to create fiscal space for public investment. In case of Tanzania, it would be useful to closely monitor the business activities of Tanzania Railway Limited (TRL), Tanzania Electric Supply Company (TANESCO), and Air Tanzania, as well as future PPPs for infrastructure investment.
} 
Fiscal rules can be defined as institutional mechanisms placing durable constraints on fiscal discretion through numerical limits on budgetary aggregates. In general, fiscal rules are a broader concept than fiscal anchors because they include institutional mechanisms to commit to anchors, and they are often enshrined in the law. To make the rules more effective, institutional reforms often follow, such as enactment of fiscal responsibility legislation or creation of nonpartisan fiscal councils. While their design features differ significantly across countries, fiscal rules generally have the following characteristics: ${ }^{11}$

- $\quad$ Procedural rules define the attributes and interactions of participants in the budget process, with the aim of enhancing transparency, accountability, and fiscal management.

- $\quad$ Numerical rules are a form of constraint on fiscal policy, typically defined in terms of indicators of overall fiscal performance.

- Coverage defines the level of government covered by the fiscal rules. The treatment of subnational governments should reflect the relevant constitutional arrangements.

- $\quad$ Sanctions and penalties for the violation of the rule could be either institutional or reputational. Institutional sanctions include suspending wage increases, overtime payments, and new hiring, and a requirement to present adjustment programs.

- $\quad$ Escape clauses provide for cases where a temporary departure from the fiscal principles is permitted. The scope and flexibility of escape clauses reflect the risks to which a country is exposed.

In practice, fiscal policy is anchored on a variety of budgetary aggregates (Table 1). Numerical limits are typically imposed on (i) the budget balance: primary or overall balances and their cyclically adjusted (CA) variants; (ii) expenditure: ceilings for nominal or real expenditure growth and the expenditure-to-GDP ratio for total or specific categories of spending; (iii) revenue: minimum target revenue or maximum tax rate; and (iv) debt: upper limit of gross or net public debt.

The trade-offs of these numerical targets make it difficult to find policy suggestions that apply universally to the choice of fiscal targets (Table 1). For instance, while a ceiling on public debt can help fend off a debt sustainability problem, short-term discipline may not be ensured because adjustments can always be postponed until the ceiling becomes binding. On the other hand, budget balance targets can more credibly ensure short-term discipline by placing constraints on short-term fiscal outturns, but they can lead to procyclical policy responses. To relieve this credibility-flexibility trade-off, combinations of targets are often used. In particular, to make an effective contribution to economic stability and debt sustainability, expenditure targets are best used to help implement deficit and debt rules.

${ }^{11}$ For cross-country comparisons of fiscal rules, see Corbacho and Schwartz (2007). 
However, a trade-off between the operational simplicity and the technical attractiveness of multiple targets often further complicates policy design.

Table 1. Comparison Matrix of Numerical Targets

\begin{tabular}{|c|c|c|}
\hline & Advantage & Disadvantage \\
\hline $\begin{array}{l}\text { Budget balance } \\
\text { target }\end{array}$ & $\begin{array}{l}\text { Convey simple and } \\
\text { important information } \\
\text { about the short-term } \\
\text { macroeconomic } \\
\text { consequences of fiscal } \\
\text { policy, including inflation } \\
\text { and balance of payments. }\end{array}$ & $\begin{array}{l}\text { - In principle, it is procyclical. } \\
\text { There are problems related to practical design, } \\
\text { monitoring and implementation of cyclically } \\
\text { adjusted (CA) variants, though the CA balance } \\
\text { target could be acyclical. }\end{array}$ \\
\hline $\begin{array}{l}\text { Expenditure } \\
\text { target }\end{array}$ & $\begin{array}{l}\text { - Make government } \\
\text { accountable for the fiscal } \\
\text { aggregate most under its } \\
\text { direct control. } \\
\text { - Could be countercyclical. }\end{array}$ & $\begin{array}{l}\text { - Risks: It could (i) lead to across-the-board or low- } \\
\text { quality adjustments; and (ii) shift the source of } \\
\text { indiscipline to the spending categories that are not } \\
\text { covered by the rules, such as the revenue side of } \\
\text { the budget and off-budget activities (an incentive } \\
\text { for creative accounting). } \\
\text { - In practice, it is difficult to define and enforce. } \\
\text { - Revenue forecasts must be reliable to ensure } \\
\text { sustainability. }\end{array}$ \\
\hline Revenue target & $\begin{array}{l}\text { - Can improve revenue } \\
\text { policy and administration. }\end{array}$ & $\begin{array}{l}\text { - It may not encourage more efficient spending. } \\
\text { - Revenue targets are rarely used in practice. }\end{array}$ \\
\hline Debt target & $\begin{array}{l}\text { - Respond directly to a debt } \\
\text { sustainability problem. } \\
\\
\text { - More flexible than flow } \\
\text { targets, while exerting } \\
\text { fiscal discipline and } \\
\text { guaranteeing debt } \\
\text { sustainability. }\end{array}$ & $\begin{array}{l}\text { - Short-term discipline may not be ensured since } \\
\text { adjustments can always be postponed until the debt } \\
\text { ceiling is reached. } \\
\text { - It may require stronger political commitment. } \\
\text { - Debt targets tend to ignore contingent liabilities. } \\
\text { - They need to be combined with other flow targets. }\end{array}$ \\
\hline \multicolumn{3}{|c|}{$\begin{array}{l}{ }^{1} \text { Cyclically adjusted balances (CABs) eliminate the cyclical components of revenue and spending from nominal fiscal } \\
\text { balances to correct procyclicality bias. While they are difficult to calculate and implement, their accuracy can be improved } \\
\text { by (i) focusing on changes in output and budget balances, rather than their levels; (ii) taking into account changes in the } \\
\text { composition of output; and (iii) using estimates of elasticities derived from tax and expenditure laws. Chile is the only } \\
\text { country that successfully targets CABs. }\end{array}$} \\
\hline
\end{tabular}

The types and legal status of fiscal rules currently in place vary, reflecting each country's specific circumstances (Table 2). ${ }^{12}$ The choice of fiscal rule is usually guided by

\footnotetext{
${ }^{12}$ In the European Union budget balance rules represent about 33 percent of numerical fiscal rules, debt and expenditure rules each about 25 percent, and revenue rules less than 10 percent (EC, 2006).
} 
considerations such as (i) the type of shocks the economy is exposed to; (ii) the state of public finances and the budgetary process; (iii) the structure and quality of fiscal institutions; (iv) whether there is fiscal decentralization; (v) relative policy priorities; and (vi) the exchange rate regime. The extent of political commitment and data availability also affect the statutory base and the coverage of the fiscal rule.

Table 2. Fiscal Rules in Selected Economies

\begin{tabular}{|c|c|c|c|c|}
\hline Country & Type of Rule & Statutory base & Coverage & Time Frame \\
\hline \multicolumn{5}{|c|}{ European Examples } \\
\hline Denmark & Structural budget balance & Political agreement & GG & Multiyear \\
\hline \multirow[t]{2}{*}{ Estonia } & Budget balance & Political agreement & GG & Multiyear \\
\hline & Debt in percent of revenues & Law & LG & Annual \\
\hline \multirow[t]{3}{*}{ Finland } & Budget balance in percent of GDP & Political agreement & CG & Multiyear \\
\hline & Budget balance & Law & LG & Multiyear \\
\hline & Debt in percent of GDP & Political agreement & CG & Multiyear \\
\hline France & Golden rule & Law & LG & Annual \\
\hline \multirow[t]{2}{*}{ Lithuania } & Ceiling on net borrowing & Law & CG & Annual \\
\hline & Budget balance & Law & LG & Annual \\
\hline Poland & Debt in percent of GDP & Constitution and Law & GG & Annual \\
\hline Slovakia & Debt in percent of revenues & Law & RG; LG & Annual \\
\hline \multirow[t]{2}{*}{ Slovenia } & Debt in percent of GDP & Coalition Agreement & GG & Multiyear \\
\hline & Debt ceilings & Law & LG & Annual \\
\hline \multirow[t]{3}{*}{ Spain } & Budget balance in percent of GDP & Law & GG & Multiyear \\
\hline & Debt ceilings & Law & RG & Annual \\
\hline & Debt in percent of revenues & Law & LG & Annual \\
\hline \multirow[t]{2}{*}{ Sweden } & Budget balance in percent of GDP & Political agreement & GG & Over the Cycle \\
\hline & Golden rule & Law & LG & Annual \\
\hline \multirow[t]{2}{*}{ United Kingdom } & Golden rule & & GG & Over the Cycle \\
\hline & Debt in percent of GDP & & GG & Over the Cycle \\
\hline \multicolumn{5}{|l|}{ Other Examples } \\
\hline \multirow[t]{2}{*}{ Argentina } & Ceilings on expenditure & Law & CG & Annual \\
\hline & Debt in percent of GDP & Law & CG & Multiyear \\
\hline Brazil & Debt in percent of revenues & Law & CG, RG, LG, & Annual \\
\hline \multirow[t]{2}{*}{ Colombia } & Debt in percent of revenues & Law & CG, LG & Annual \\
\hline & Debt service in percent of operational surplus & Law & CG, LG & Annual \\
\hline \multirow[t]{4}{*}{ Peru } & Budget balance in percent of GDP & Law & NFPS & Annual \\
\hline & Primary balance on average & Law & LG & Multiyear \\
\hline & Debt service in percent of revenue & Law & LG & Annual \\
\hline & Debt in percent of revenues & Law & LG & Annual \\
\hline USA & Ceilings on expenditure & Law & CG & $\begin{array}{l}\text { Annual. Expired since the } \\
\text { ceilings were set to } \\
\text { achieve balanced budget } \\
\text { by } 2002 \text {. }\end{array}$ \\
\hline New Zealand & Operational balance & Law & GG & Multiyear \\
\hline
\end{tabular}

$\mathrm{GG}=$ General Government, $\mathrm{RG}=$ Regional Government, $\mathrm{LG}=$ Local Government, NFPS= Nonfinancial Public Sector

Many sub-Saharan African (SSA) countries have adopted fiscal rules (Table 3). Most of them are based on international treaties and cover general government. About 70 percent of countries with fiscal rules have more than one target (e.g., budget balance and public debt); most of those with a single target focus on budget balance. In francophone SSA, the eight countries of the West Africa Economic and Monetary Union (WAEMU) and the six countries of the Central Africa Economic and Monetary Union (CEMAC) are subject to 
fiscal rules similar to those of the European Union (EU). ${ }^{13}$ In particular, the Convergence, Stability, Growth, and Solidarity Pact WAEMU governments adopted in 1999 calls for (i) a non-negative basic fiscal balance, defined as domestic revenue minus expenditure excluding foreign-financed investment); and (ii) a debt-to-GDP ratio of less than 70 percent ${ }^{14}$ However, as in the EU countries, the WAEMU Commission has difficulty in ensuring compliance with these targets.

Among the countries with individual fiscal rules, Kenya has politically committed to hold revenue steady at 21-22 percent of GDP and reduce total public debt below 40 percent of GDP; Namibia has a debt ceiling of 30 percent of GDP, which is supported by coalition agreement; and Nigeria's fiscal responsibility law (FRL) requires that any annual deficit be less than 3 percent of GDP. The fiscal anchor in Namibia is considered effective; it has provided the discipline to reduce public debt from about 34 percent of GDP in 2004/05 to about 24 percent in 2007/08. However, the Kenyan and Nigerian fiscal rules are too recent for their benefits to be assessed.

International experience with fiscal rules, mostly in advanced economies, suggests that they may be useful in ensuring fiscal discipline and improving fiscal outcomes. In a review of experiences in EU member states, the EC (2006) finds evidence of a link between numerical fiscal rules and fiscal outcomes, including improvements in the primary balance and the decline of CA primary expenditure after fiscal rules were introduced. The benefits of institutional reforms, such as FRLs, are also identified in the literature. By providing a clear signal about a government's commitment to monitorable fiscal policy outcomes and strategies, fiscal rules enshrined in the law that include an automatic enforcement mechanism tend to be more effective in affecting fiscal outcomes. ${ }^{15}$ However, international experience also confirms that a fiscal rule is not a panacea - it can be circumvented, ignored, or abandoned, and a rule cannot replace broad political consensus and commitment to fiscal discipline.

\footnotetext{
${ }^{13}$ WAEMU comprises Benin, Burkina Faso, Côte d'Ivoire, Guinea-Bissau, Mali, Niger, Senegal, and Togo. CEMAC comprises Cameroon, Central African Republic, Chad, Congo, Equatorial Guinea, and Gabon.

${ }^{14}$ While CEMAC has adopted similar objectives, its monitoring mechanisms are weaker than in WAEMU.

${ }^{15}$ Many studies advocate establishment of a fiscal council (see, e.g., Debrun, Hauner, and Kumar, 2007). Fiscal councils can provide independent macroeconomic and fiscal projections, conduct fiscal analysis, issue binding or nonbinding recommendations, and thus raise public awareness and debate about fiscal issues, which could enhance the effectiveness of fiscal rules. However, the EC (2006) concludes that there is so much variety in such institutions in EU member states that it is difficult to find evidence of their impact on the conduct of fiscal policy.
} 
Table 3. Fiscal Rules in Sub-Saharan African Countries

\begin{tabular}{|c|c|c|c|c|c|c|c|c|}
\hline Country & $\begin{array}{c}\text { Type of } \\
\text { Rule }\end{array}$ & & $\begin{array}{l}\text { Statutory } \\
\text { Base }\end{array}$ & Coverage & $\begin{array}{c}\text { Time } \\
\text { Frame }\end{array}$ & $\begin{array}{c}\text { Year of } \\
\text { Adoption }\end{array}$ & $\begin{array}{c}\text { Formal } \\
\text { Enforcement }\end{array}$ & Remarks \\
\hline Benin & $\begin{array}{l}\text { Budget } \\
\text { balance rule } \\
\text { (BBR); } \\
\text { debt rule } \\
\text { (DR) }\end{array}$ & & $\begin{array}{l}\text { International } \\
\text { treaty }\end{array}$ & $\begin{array}{l}\text { General } \\
\text { government } \\
(\mathrm{GG})\end{array}$ & Annual & 1999 & BBR & $\begin{array}{l}\text { WAEMU has several fiscal } \\
\text { convergence criteria that } \\
\text { might be considered to } \\
\text { constitute a fiscal rule. } \\
\text { However, they are not } \\
\text { binding, and almost all } \\
\text { member countries have } \\
\text { missed some at one point } \\
\text { or another. WAEMU may } \\
\text { either reset the horizon or } \\
\text { change the rule since two } \\
\text { convergence deadlines } \\
\text { (2005 and 2008) have been } \\
\text { missed. These probable } \\
\text { changes are related to the } \\
\text { current financial crisis. }\end{array}$ \\
\hline Botswana & $\begin{array}{l}\text { Expenditure } \\
\text { rule (ER) }\end{array}$ & & - & $\begin{array}{l}\text { Local } \\
\text { government } \\
\text { (LG) }\end{array}$ & - & 2003 & - & $\begin{array}{l}\text { The fiscal rule requires that } \\
\text { expenditures not exceed } \\
40 \text { percent of GDP. } \\
30 \text { percent of total } \\
\text { expenditure should be } \\
\text { directed toward } \\
\text { development spending. }\end{array}$ \\
\hline Burkina Faso & BBR, DR & & $\begin{array}{l}\text { International } \\
\text { treaty }\end{array}$ & GG & Annual & 1999 & BBR & WAEMU. See Benin. \\
\hline Cameroon & BBR, DR & & $\begin{array}{l}\text { International } \\
\text { treaty }\end{array}$ & GG & Annual & $\begin{array}{l}1996 \\
\text { (BBR); } \\
2002 \text { (DR) }\end{array}$ & BBR & - \\
\hline Cape Verde & $\mathrm{BBR}, \mathrm{DR}$ & & & $\mathrm{CG}$ & Annual & 1998 & $\mathrm{BBR}, \mathrm{DR}$ & $\begin{array}{l}\text { The rule has not been } \\
\text { binding recently. }\end{array}$ \\
\hline $\begin{array}{l}\text { Central } \\
\text { African } \\
\text { Republic }\end{array}$ & $\mathrm{BBR}, \mathrm{DR}$ & & $\begin{array}{l}\text { International } \\
\text { treaty }\end{array}$ & GG & Annual & $\begin{array}{l}1996 \\
\text { (BBR); } \\
2002(\mathrm{DR})\end{array}$ & BBR & - \\
\hline Chad & $\mathrm{BBR}, \mathrm{DR}$ & $\mathrm{i}$ & $\begin{array}{l}\text { International } \\
\text { treaty }\end{array}$ & GG & Annual & $\begin{array}{l}1996 \\
\text { (BBR); } \\
2002(\mathrm{DR})\end{array}$ & BBR & - \\
\hline
\end{tabular}




\begin{tabular}{|c|c|c|c|c|c|c|c|}
\hline Comoros & BBR & Constitution & CG & Annual & 2001 & BBR & Franc zone rule \\
\hline Congo & BBR, DR & $\begin{array}{l}\text { International } \\
\text { treaty }\end{array}$ & GG & Annual & $\begin{array}{l}1996 \\
\text { (BBR); } \\
2002(\mathrm{DR}) \\
\end{array}$ & BBR & - \\
\hline Côte d'Ivoire & $\mathrm{BBR}, \mathrm{DR}$ & $\begin{array}{l}\text { International } \\
\text { treaty }\end{array}$ & GG & Annual & 1999 & BBR & WAEMU. See Benin. \\
\hline $\begin{array}{l}\text { Equatorial } \\
\text { Guinea }\end{array}$ & $\mathrm{BBR}, \mathrm{DR}$ & $\begin{array}{l}\text { International } \\
\text { treaty }\end{array}$ & GG & Annual & $\begin{array}{l}1996 \\
\text { (BBR); } \\
2002(\mathrm{DR})\end{array}$ & BBR & $\begin{array}{l}\text { The fiscal rule is based on } \\
\text { the permanent income } \\
\text { model. The authorities } \\
\text { have committed to reaching } \\
\text { a sustainable non-oil } \\
\text { primary deficit over the } \\
\text { medium-term. }\end{array}$ \\
\hline Gabon & $\mathrm{BBR}, \mathrm{DR}$ & $\begin{array}{l}\text { International } \\
\text { treaty }\end{array}$ & GG & Annual & $\begin{array}{l}1996 \\
\text { (BBR); } \\
2002(\mathrm{DR})\end{array}$ & BBR & $\begin{array}{l}\text { Gabon is a member of } \\
\text { CEMAC and as such has a } \\
\text { limit on its deficit and total } \\
\text { debt. }\end{array}$ \\
\hline Gambia & BBR & $\begin{array}{l}\text { International } \\
\text { treaty }\end{array}$ & GG & Annual & 2001 & - & - \\
\hline Ghana & BBR & $\begin{array}{l}\text { International } \\
\text { treaty }\end{array}$ & GG & Annual & 2001 & - & - \\
\hline Guinea & BBR & $\begin{array}{l}\text { International } \\
\text { treaty }\end{array}$ & GG & Annual & 2001 & - & - \\
\hline Guinea Bissau & $\mathrm{BBR}, \mathrm{DR}$ & $\begin{array}{l}\text { International } \\
\text { treaty }\end{array}$ & GG & Annual & 1999 & BBR & WAEMU. See Benin. \\
\hline Kenya & $\begin{array}{l}\text { Revenue } \\
\text { rule (RR), } \\
\text { DR }\end{array}$ & $\begin{array}{l}\text { Political } \\
\text { commitment }\end{array}$ & CG & Annual & 2008 & - & $\begin{array}{l}\text { Hold revenue steady at } 21- \\
22 \text { percent of GDP; reduce } \\
\text { the debt-to-GDP ratio to } \\
\text { below } 40 \text { percent; limit } \\
\text { government overdraft at the } \\
\text { central bank limited to } \\
5 \text { percent of previous } \\
\text { year's revenue. The DR } \\
\text { allows for a temporary } \\
\text { departure from the ceiling. }\end{array}$ \\
\hline Liberia & BBR & & & & - & - & $\begin{array}{l}\text { The authorities operate a } \\
\text { cash-based budget, which } \\
\text { implies a BBR. }\end{array}$ \\
\hline
\end{tabular}




\begin{tabular}{|c|c|c|c|c|c|c|c|}
\hline Mali & $\mathrm{BBR}, \mathrm{DR}$ & $\begin{array}{l}\text { International } \\
\text { treaty }\end{array}$ & GG & Annual & 1999 & $\mathrm{BBR}$ & $\begin{array}{l}\text { WAEMU. See Benin. In } \\
2008 \text {, Mali did not meet } \\
2 \text { of } 5 \text { primary criteria and } \\
3 \text { of } 4 \text { secondary criteria. }\end{array}$ \\
\hline Mauritius & $\begin{array}{l}\text { ER, BBR, } \\
\text { DR }\end{array}$ & Statutory & $\mathrm{CG}$ & $\begin{array}{l}\text { Multiyear } \\
\text { for ER }\end{array}$ & 2008 & ER, BBR, DR & - \\
\hline Namibia & DR & $\begin{array}{l}\text { Coalition } \\
\text { agreement }\end{array}$ & $\mathrm{CG}$ & Annual & 2001 & - & $\begin{array}{l}\text { The ceiling on public debt } \\
\text { is raised from } 25 \text { percent of } \\
\text { GDP to } 30 \text { percent over the } \\
\text { MTEF period (2009-12). }\end{array}$ \\
\hline Niger & $\mathrm{BBR}, \mathrm{DR}$ & $\begin{array}{l}\text { International } \\
\text { treaty }\end{array}$ & GG & Annual & 1999 & BBR & $\begin{array}{l}\text { WAEMU. See Benin. } \\
\text { Niger met all rules during } \\
2008 \text {, which was the } \\
\text { horizon set for } \\
\text { convergence. }\end{array}$ \\
\hline Nigeria & $\mathrm{RR}, \mathrm{BBR}$ & Statutory & $\mathrm{GG}, \mathrm{CG}$ & Annual & 2007 & - & $\begin{array}{l}\text { The FRL contains an } \\
\text { annual } 3 \text { percent deficit } \\
\text { ceiling. The ceiling can be } \\
\text { breached "if in the opinion } \\
\text { of the President there is a } \\
\text { clear and present threat to } \\
\text { national security or } \\
\text { sovereignty." The } 2009 \\
\text { budget breaches the ceiling } \\
\text { by a narrow margin. }\end{array}$ \\
\hline Senegal & $\mathrm{BBR}, \mathrm{DR}$ & $\begin{array}{l}\text { International } \\
\text { treaty }\end{array}$ & GG & Annual & 1999 & BBR & WAEMU. See Benin. \\
\hline Sierra Leone & BBR & $\begin{array}{l}\text { International } \\
\text { treaty }\end{array}$ & GG & Annual & 2001 & - & - \\
\hline Togo & $\mathrm{BBR}, \mathrm{DR}$ & $\begin{array}{l}\text { International } \\
\text { treaty }\end{array}$ & GG & Annual & 1999 & BBR & WAEMU. See Benin. \\
\hline
\end{tabular}

Source: IMF staff. 


\section{A Possible Medium-Term Fiscal Policy Framework for Tanzania}

As a first step, it needs to be specified what could be an optimal fiscal anchor for Tanzania. While this requires consideration of country-specific circumstances, policy priorities, and lessons from international experience, Kopits and Symansky (1998) suggest four principles to guide a country's choice: a rule should be (i) simple, well-defined, and relatively easy to monitor; (ii) flexible, to accommodate shocks, allow the operation of automatic stabilizers, and thus avoid procyclical fiscal policy; (iii) transparent, so as not to give rise to distortions and unsavory accounting practices; and (iv) internally consistent and enforceable.

In Tanzania, the importance of avoiding reaccumulation of unsustainable public debt suggests that medium-term fiscal policy could be guided by a "diamond rule" consisting of a fiscal anchor and three complementary benchmarks (see Figure 2). A permanent hard ceiling on public debt could ensure debt sustainability while enabling flexible policy responses to business cycles and development needs. In addition, annual benchmarks for NDF, expenditure growth, and concessionality would guide short-term fiscal policy by helping prevent a rapid deterioration of the fiscal position and economic stability in the short term. Both the ceiling and the benchmarks would represent limits, not targets for fiscal policy.

As its flexibility could help define the fiscal space available for countercyclical fiscal policy and sustainable development spending, anchoring fiscal policy on a public debt target would be appealing for Tanzania. However, while gross public debt is a common fiscal anchor, it could be misleading if used for assessing Tanzania's fiscal sustainability. At the end of 2008 total public debt was about 40 percent of GDP (domestic debt of 15 percent and concessional external debt of 25 percent). However, the present value (PV) of total public debt, which is widely accepted as a fiscal sustainability indicator, is $25 \frac{1}{2}$ percent of GDP due to the concessionality of external debt. The extent to which fiscal sustainability is affected by changes in the composition of external debt (concessional vs. commercial) needs to be better reflected in the PV of total public debt.

\section{Components of a Diamond Rule}

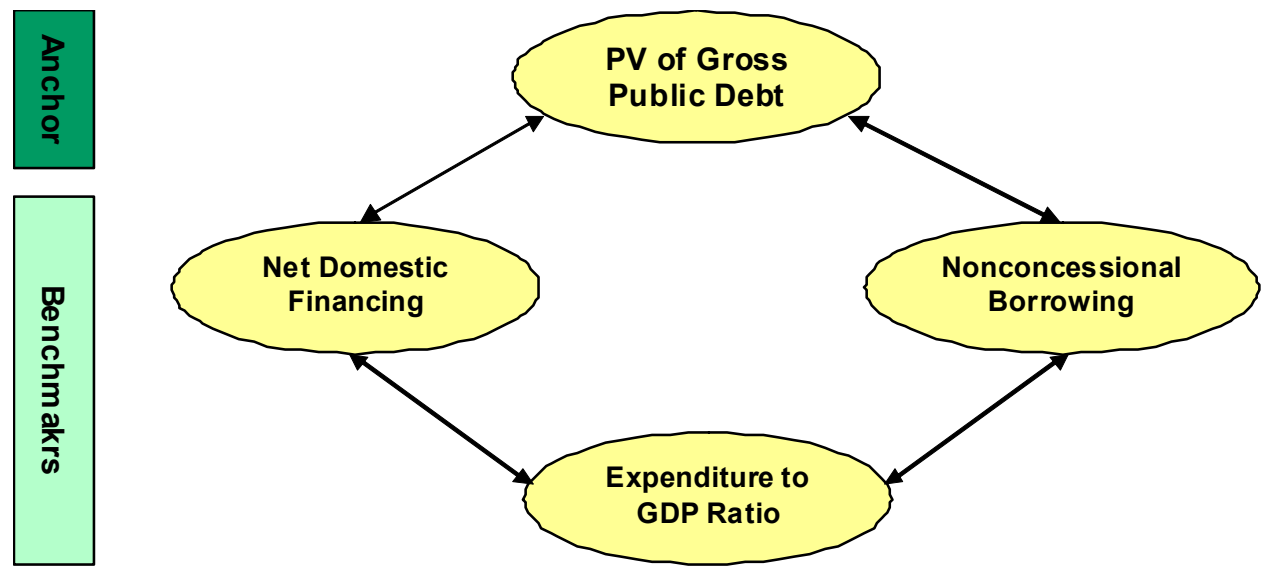


It is very difficult to pin down a desirable debt-to-GDP ratio; each country has a different debt tolerance, depending on the magnitude of economic shocks to growth, the interest rate, the exchange rate, etc. For this reason, how much public debt is sustainable is to some extent a matter of judgment and considerations of various trade-offs. While a very low debt target could be prudent in many emerging market economies, it would require a tight fiscal stance for an extended period of time, which might have the cost of lower public investment and slower improvement in development indicators. On the other hand, a higher debt target could provide more short-term resources for such spending, but at the cost of raising sustainability concerns and debt service payments that could constrain other essential spending.

To narrow the room for judgment in assessing the desirable level of public debt for Tanzania, it is useful to compare its debt with that of other emerging market countries (EMCs) and review the empirical literature on public debt sustainability. Gross debt dynamics in 48 EMCs in the last decade indicate that after peaking at over 55 percent of GDP in 2003, the average debt-to-GDP ratio began to decline rapidly; reaching 42 percent in 2008 (the median was 38 percent). IMF (2003) provides useful findings that (i) while the level of public debt at the time of default has varied significantly, a crisis can happen even when debt is very low (in 35 percent of the default cases analyzed, debt was less than 40 percent of GDP); and (ii) as debt increases, primary balance corrections for debt stabilization weaken to the point that they stop completely when the debt-to-GDP ratio reaches about 50 percent. ${ }^{16}$

Keeping the PV of public debt below 40 percent of GDP could thus be an appropriate anchor for Tanzania's medium-term fiscal policy. To minimize operational complexity and improve policy transparency, the rule for the PV calculation should be clearly set before a specific ceiling is announced. However, given the relatively large space between the PV of current public debt and the proposed ceiling, to ensure short-term fiscal discipline it would be useful to complement the debt anchor with benchmark limits on annual budgetary financing and spending.

An NDF benchmark could help prevent a rapid build-up of domestic debt, which would raise concerns about policy credibility and economic stability. Experiences with NDF targeting have been encouraging in recent years, and there has also been considerable progress in improving the efficiency and absorption capacity of Tanzania's domestic credit market. Therefore, a benchmark NDF ceiling of $2 \frac{1}{2}$ percent of GDP could provide a reasonable policy constraint to ensure short-term fiscal discipline.

The terms of deficit financing for large infrastructure investment projects could also be a source of fiscal vulnerability. Given that currently Tanzania's gross public debt stands at about 40 percent of GDP while its PV is around 251/2 percent, replacing concessional debt with commercial one could push the PV of gross public debt to the proposed ceiling without providing any additional resources for investment. For this reason, a benchmark limit on

\footnotetext{
${ }^{16}$ This implies that, on average, fiscal policy in the EMCs ceases to be consistent with debt sustainability once debt reaches 50 percent of GDP.
} 
nonconcessional external borrowing (say, 21/2 percent of GDP) would provide useful guidance and a constraint on medium-term policy. ${ }^{17}$

Ceilings on the PV of public debt, as well as benchmark limits on NDF and nonconcessional external borrowing, may not be effective in discouraging procyclical expenditure policy, particularly when the financing resources identified are greater than the economy can absorb. Unless expenditure policy discretion is constrained, the financing side of the budget is likely to direct the policy, which could undermine both spending efficiency and the stability of the economy if there are supply constraints. A benchmark limit of the annual change in expenditure-to-GDP ratio to 3 percent of GDP could therefore be useful to break the procyclical bias of expenditure policy. ${ }^{18}$

The diamond rule could help shape the budget preparation process by defining sustainable fiscal space and providing benchmark limits on key budgetary aggregates. The rule also allows for more flexible fiscal policy than the current zero NDF target. However, the potential impact of domestic financing on the domestic credit market warrants further consideration. In particular, despite recent efforts to develop the domestic government bond market, it will still be difficult to use the domestic market to finance infrastructure because of (i) the need to build up a long-term securities market to reduce rollover and liquidity risks in funding infrastructure; and (ii) the possibility of a crowding-out effect that will impair the ability of the real economy to access credit.

Additional efforts to strengthen public financial management (PFM) systems and processes to ensure adequate emphasis on budget preparation and execution are needed to secure the benefits of adopting the diamond rule. As reiterated by the government, infrastructure investment will be a priority of medium-term fiscal policy. While a sustained increase in public investment is certainly necessary to meet Tanzania's development objectives, the additional fiscal space for public investment that fiscal rules could help define is not enough to ensure its growth- and welfare-enhancing effects without complementary measures to improve how the money is allocated and spent. To safeguard policy consistency and the quality of spending, further progress in the following PFM areas is necessary:

- $\quad$ Public investment should be identified within the budgetary process with broad coverage, including central and local governments and state-owned enterprises.

\footnotetext{
${ }^{17}$ Without any other financing, the NDF target and the benchmark ceiling on nonconcessional external borrowing imply limiting the deficit to less than 5 percent of GDP.

${ }^{18}$ Expenditure rules are often highly recommended for a fiscal anchor. However, Tanzania has had a relatively poor expenditure forecasting record, possibly because of limited capacity in public financial management or less predictable general budget support. It has an average year-ahead forecasting error of about 6 percent of expenditure compared to less than 1 percent for countries that have managed to make expenditure rules work. It would therefore be difficult to enforce any kind of strict expenditure rules ex post with so much noise in the system.
} 
- $\quad$ Public expenditure reviews need to be integral to the expenditure allocation process and expenditure policy needs to be reprioritized within and across sectors.

- $\quad$ The MTEF should be more integrated with the annual budget process as a foundation for preparing the budget.

- $\quad$ Project execution rates need to be increased by improving project management and procurement practices.

It would be ideal if a fiscal rule reflected a broad political consensus in the country. Enshrining fiscal targets in an FRL could solidify the importance of the fiscal anchor. However, imposing legal constraints on budgetary aggregates without a firm political commitment would jeopardize the credibility of the rule. Given the country's lack of experience with a rule-based MTFPF, the diamond rule in Tanzania could start as a political objective of the government that should be clearly spelled out during election campaigns, at the beginning of its term in office, or in the MKUKUTA. This would subject fiscal policy to more intense public scrutiny, and departure from the objective would be more costly. Eventually it would be desirable to build a broad political consensus and eventually codify the fiscal rule. ${ }^{19}$ It would also be useful to improve institutional arrangements that can provide a clear allocation of fiscal responsibilities. Establishing a fiscal council could also strengthen fiscal policy by providing independent macrofiscal projections and fiscal policy assessment and advice.

\section{Application of the Proposed Diamond Rule to Tanzania}

The diamond rule would provide some flexibility for countercyclical fiscal policy. The fact that there is fiscal room for stabilization policy does not necessarily guarantee that countercyclical policy will be effective given the practical difficulties in implementing discretionary policy in "timely, temporary, and targeted" ways. However, the proposed rule will ensure fiscal room to accommodate automatic stabilizers, which is generally considered the most effective way to stabilize but would have to be offset under the current zero NDF targeting.

Tanzania's adopting the diamond rule could also stimulate discussions on the convergence criteria for regional economic integration. The EAC recently reiterated a plan to establish a monetary union by 2012, but discussions on the institutional structure of the union and convergence criteria have yet to begin. As the Convergence Criteria and the Stability and Growth Pact (SGP) of the Economic and Monetary Union (EMU) of the European Union requires, budgetary discipline in member states would be essential to a sustainable monetary

\footnotetext{
${ }^{19}$ A few years ago, the IMF proposed that an FRL to be introduced in Tanzania; this was viewed at the time as a way to ring-fence reforms at a delicate juncture. A consensus was then reached that a new law would not be needed because specific elements of the PFM framework, such as the Public Finance Act and its regulations, could be modified to meet the intended purpose.
} 
union. The diamond rule could set a reasonable ground for discussion among member states on how to coordinate national government budget policies and avoid excessive budget deficits and debt accumulation. ${ }^{20}$

This section analyzes how the diamond rule can be used to define fiscal space for more infrastructure investment consistent with medium-term fiscal sustainability.

\section{Background}

Tanzania has had sustained high rates of broad-based economic growth with generally low inflation for the past decade. Real GDP growth averaged about 7 percent a year for 2000-08. Inflation was kept solidly in check for much of this period, but it accelerated in 2008 (13.5 percent at year-end), driven mainly by lagged effects of the spike in international food and fuel prices ${ }^{21}$ and more recently by regional food supply shocks. Nonfood inflation has been modest (5.8 percent). Solid growth in tax revenues for the past five years and substantial donor support have allowed the government to expand spending rapidly with only limited recourse to domestic financing. Tanzania also built up substantial official international reserves, partly reflecting export growth. As of 2008, gross international reserves were about US\$2.8 billion (more than 4 months of imports of goods and services).

Tanzania has benefited from extensive debt relief from the HIPC Initiative and more recently the Multilateral Debt Relief Initiative (MDRI). As of June 2008, Tanzania's public external debt was US $\$ 3.7$ billion (20.9 percent of GDP); compared with US\$7.2 billion (53.4 percent of GDP) at June 2006, two years before MDRI relief became effective. ${ }^{22}$ About half of total external debt is owed to multilaterals. Tanzania's domestic debt increased from Tsh 2.5 trillion (14.5 percent of GDP) at end-June 2006 to Tsh 3.3 trillion (14.3 percent) at end-June 2008, about half of which was short-term Treasury bills. Tanzania is classified as a strong performer according to the three-year moving average index of the World Bank's Country Performance and Institutional Assessment (CPIA).

\section{Medium- to long-term macroeconomic and financing assumptions}

The baseline scenario assumes that the Tanzanian economy recovers gradually from the slowdown caused by the global economic and financial crisis. After falling to 4-5 percent in 2009 (5.3 percent in 2009/10), real GDP growth is projected to increase gradually to

\footnotetext{
${ }^{20}$ The EMU's convergence criteria and SGP require that government deficit and debt not exceed 3 percent and 60 percent of GDP, respectively. The economic rationale behind limiting fiscal discretion is that the stability of a monetary union could be threatened by inflationary biases in highly indebted countries. However, some argue that constraining fiscal policy could undermine the stability of a monetary union by limiting members' ability to respond to asymmetric shocks when there are price rigidities.

${ }^{21}$ See "Impact of Rising International Food and Fuel Prices on Inflation in EAC Countries", in Rwanda and Uganda-Selected Issues (SM/08/353).

${ }^{22}$ The debt stock excludes estimated interest arrears of about US\$560 million, which are expected to be canceled upon conclusion of formal agreements on HIPC debt relief. Most of these arrears are associated with bilateral debt. It also excludes undisbursed committed debt of US $\$ 2.3$ billion.
} 
7.5 percent in $2012 / 13,{ }^{23}$ driven partly by the government stepping up spending on infrastructure investment by 2 percentage points of GDP annually. Growth is assumed to remain at 7.5 percent for five years before gradually declining to a long-run rate of 6 percent in 2019/20 and beyond as the impact of the stepped-up infrastructure investment diminishes. Inflation (GDP deflator) is also projected to decelerate to the Bank of Tanzania's mediumterm objective of 5 percent by 2011/12 as the impact of high food and fuel prices subsides, ${ }^{24}$ and then remain unchanged through 2028/29. Reflecting the projected path of CPI inflation, the annual average real exchange rate is projected to appreciate modestly in 2009/10 and 2010/11 and then hold constant through 2028/29. Both the export and import price index deflators are assumed to grow at 2 percent a year. The income elasticity used for export and import projections is 1.25 and 1.1, respectively, which helps gradually narrow the external current account deficit over the long term and gradually increase national saving (both private and public).

To finance the additional infrastructure spending, the baseline incorporates additional domestic and external borrowing on nonconcessional terms. Given the difficulty of accessing foreign credit markets during the current crisis, initially the additional borrowing is obtained from domestic sources (total projected NDF is 1.2 percent of GDP in 2008/09 and 1.6 percent in 2009/10). Thereafter, the additional borrowing needs ( 2 percent of GDP in 2010/11-2014/15) are assumed to be evenly split between domestic and foreign financing. The terms assumed are as follows: interest on new domestic borrowing is 12 percent (with automatic rollover of debt) and interest on foreign borrowing is 9 percent (with a 1-year grace period and 10-year maturity). ${ }^{25}$ The elevated infrastructure investment is reflected in an initial increase in development spending, from 8.8 percent of GDP in 2008/09 to 10.9 percent in 2010/11. After that, development spending falls to about 10.5 percent of GDP on average

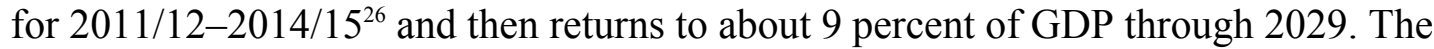
baseline also accounts for annual maintenance costs of 5 percent of the total value of the accumulated additional infrastructure spending, about 0.2 percent of GDP in 2014/15, before gradually declining relative to GDP through the rest of the projection period. Maintenance costs are added to recurrent costs.

Government revenues are assumed to increase - though more gradually than in recent years - and external grants to decline. Roughly in line with the Tanzania Revenue Authority's objective, government revenues are assumed to rise from 16 percent of GDP in $2009 / 10$ to plateau at about 20 percent by 2017/18. External grants are assumed to decline

\footnotetext{
${ }^{23}$ Tables and figures are in fiscal years (July-June). For example, 2009 refers to fiscal year 2009/10.

${ }^{24}$ Inflation had accelerated to 13.0 percent by March 2009, driven mainly by lagged effects of the spike in international food and fuel prices and more recently by regional food shortages. Nonfood inflation, however, declined to 4.3 percent.

${ }^{25}$ An interest parity between domestic and foreign borrowing is assumed only for new borrowing. Debt service figures on existing public debt (both domestic and foreign) are provided by the authorities.

${ }^{26}$ After 2010/11, it is expected that MDRI resources that were available for propoor development spending will be exhausted, which explains the drop in development spending thereafter.
} 
from 6 percent of GDP in 2009/10 to 4.5 percent by 2014/15 and also remain there. Foreign concessional loans (in U.S. dollar terms) are assumed to grow at 4 percent a year. As a result, concessional loans fall from 4 percent of GDP in 2009/10 to 1.5 percent by 2028/29, as Tanzania gradually reduces its aid dependency.

\section{Baseline}

The proposed increase in infrastructure spending over the medium term (2009/10-2014/15) allows development spending to average 10.4 percent of GDP. The elevated development spending would be financed by an increase in nonconcessional borrowing of about $2-3 \frac{1}{2}$ percent of GDP during this period (about 1 percent of GDP from external sources and the rest from domestic sources), a total of US\$4.4 billion.

Figure 2. Tanzania: Indicators of Public Debt, 2008-2028 Baseline
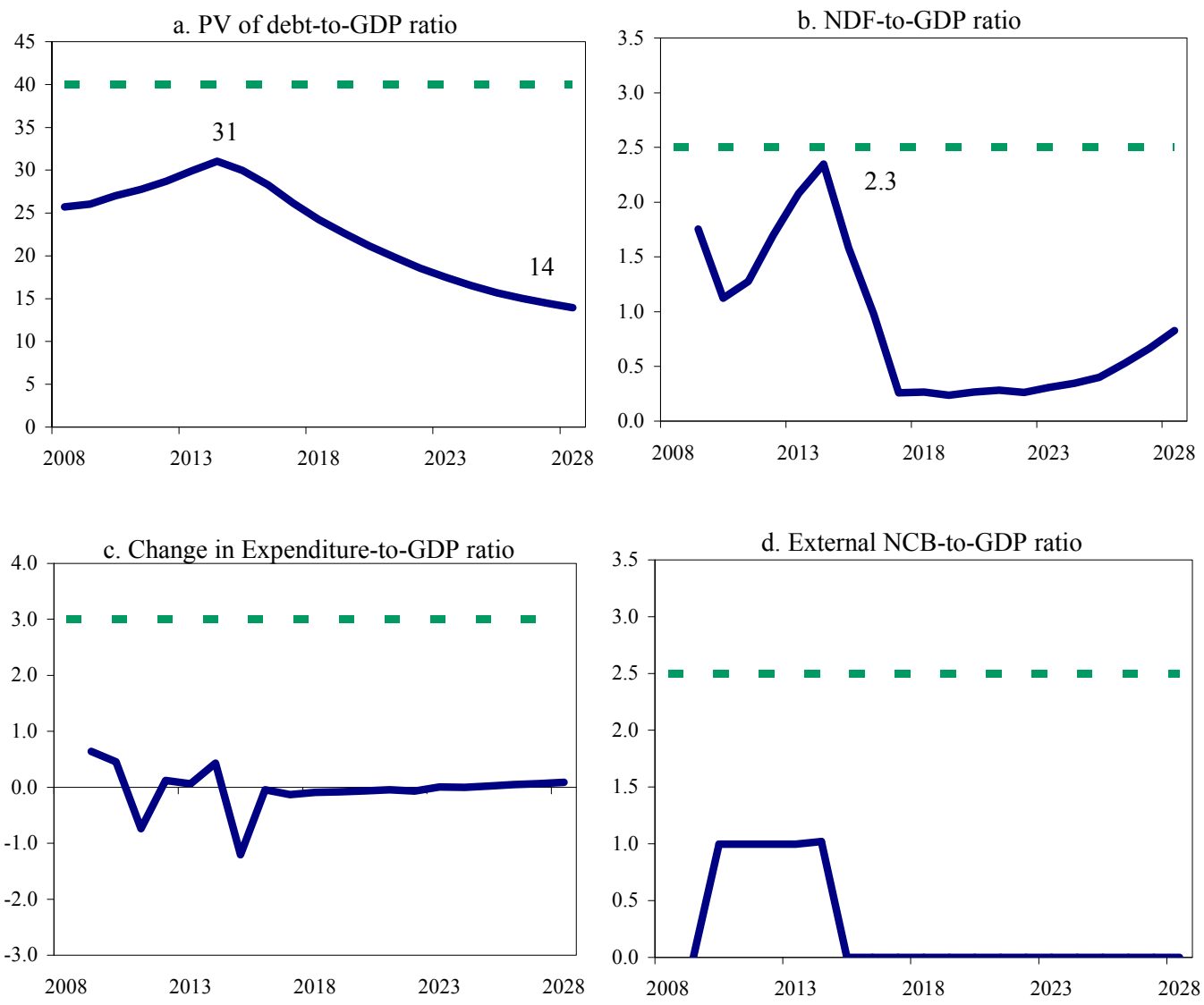

The additional borrowing proposed in the baseline would increase the debt indicators temporarily but should not jeopardize long-run sustainability (Figure 2). Tanzania's total public sector debt was Tsh 8.1 billion, 35.2 percent of GDP, at mid-year 2008-about $25 \frac{1}{2}$ percent in PV terms. The PV of debt-to-GDP ratio would increase to 31 percent of GDP in the medium-term before falling to about 14 percent by 2029 . The bound tests and 
alternative scenarios of the standard debt sustainability analysis (DSA) generally support the assessment that Tanzania's debt outlook is benign. ${ }^{27}$

The baseline scenario is, however, sensitive to the assumptions made about real GDP growth and donor support. Assuming annual real GDP growth of 6.0 percent over the projection period (i.e., the stepped-up investment over the next several years has no positive impact on real GDP growth beyond the assumed longterm growth rate) and leaving the baseline path of non-interest government spending unchanged in nominal terms would imply a significant increase in debt indicators over time. Moreover, if grants were to grow only at the same rate as foreign loans (4 percent a year in U.S. dollar terms), grants would fall from 4.5 percent to 2.4 percent of GDP by $2028 / 29$. If a lower-growth scenario were to be coupled with lower growth in grants, the PV of public debt would reach 86 percent of GDP in $2028 / 29$, of which the external debt portion would be 42 percent of GDP. Though the PV of external public debt remains below the relevant indicative threshold for Tanzania, this alternative scenario highlights the importance

PV of Debt-to-GDP Ratio, 2008-2028: Lower Growth of Output and Grants 1/

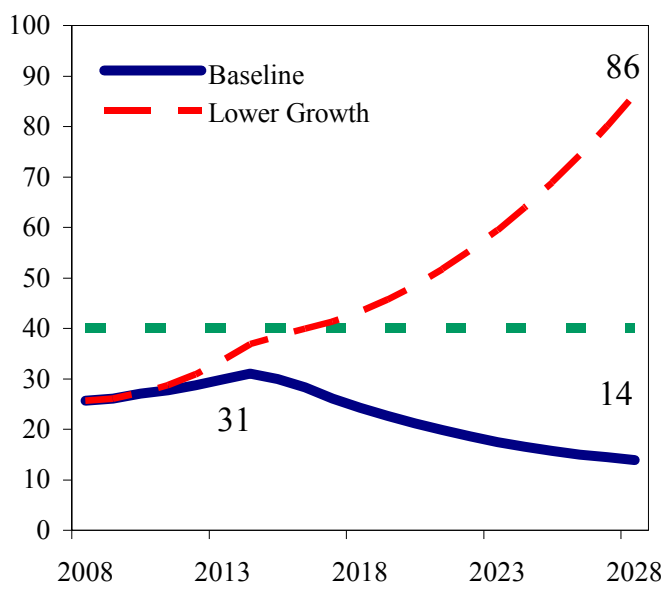

1/ Assumes: real GDP growth remains at 6 percent during the medium- and long-term, and grants (in US dollars) grow at 4 percent during 2015-29. of sound debt management — and possible

fiscal adjustment - and careful evaluation of infrastructure projects to ensure a healthy return on investment.

\section{Implications of the Diamond Rule in the baseline}

The diamond rule consists of a fiscal anchor, which is a permanent hard ceiling on public debt, and three complementary annual benchmark limits, on NDF, expenditure growth, and concessionality. As noted, the anchor is set to enable flexible policy responses to business cycles and development needs without jeopardizing long-run debt sustainability. The three annual benchmark limits are set to act as speed bumps to prevent a rapid short-term deterioration of the fiscal position and economic stability.

A numerical illustration of the fiscal anchor and the three benchmarks can be drawn from the medium- to long-term macroeconomic and financing assumptions in the baseline. For example, if Tanzania's total public debt were to reach and to remain at 40 percent of GDP (the PV would be equivalent in the long run, given the gradual decline in the role of concessional loans assumed in the baseline), the debt-stabilizing primary balance would have

\footnotetext{
${ }^{27}$ See Joint World Bank/IMF Debt Sustainability Analysis for Tanzania, IMF Country Report No. 09/179.
} 
to be 0.3 percent of GDP ${ }^{28}$ Interest payments on that amount of debt would be about 4.3 percent of GDP. This implies that the overall deficit consistent with this ceiling for debt would be about 4.0 percent of GDP.

The overall fiscal deficit that is consistent with the diamond rule's debt ceiling makes an important point: the benchmarks on NDF and external nonconcessional borrowing (NCB) cannot both be binding if they are to act as speed bumps. Simulations (see below) show that the NDF and NCB need to be kept at about 1.6 percent of GDP to keep debt below the ceiling through the projection period. Indeed, if benchmarks of 2.5 percent of GDP on both NDF and NCB were to become binding beyond the medium term, the PV of debt-to-GDP ratio would reach the diamond rule's debt ceiling by 2018 and then rise through the ceiling.
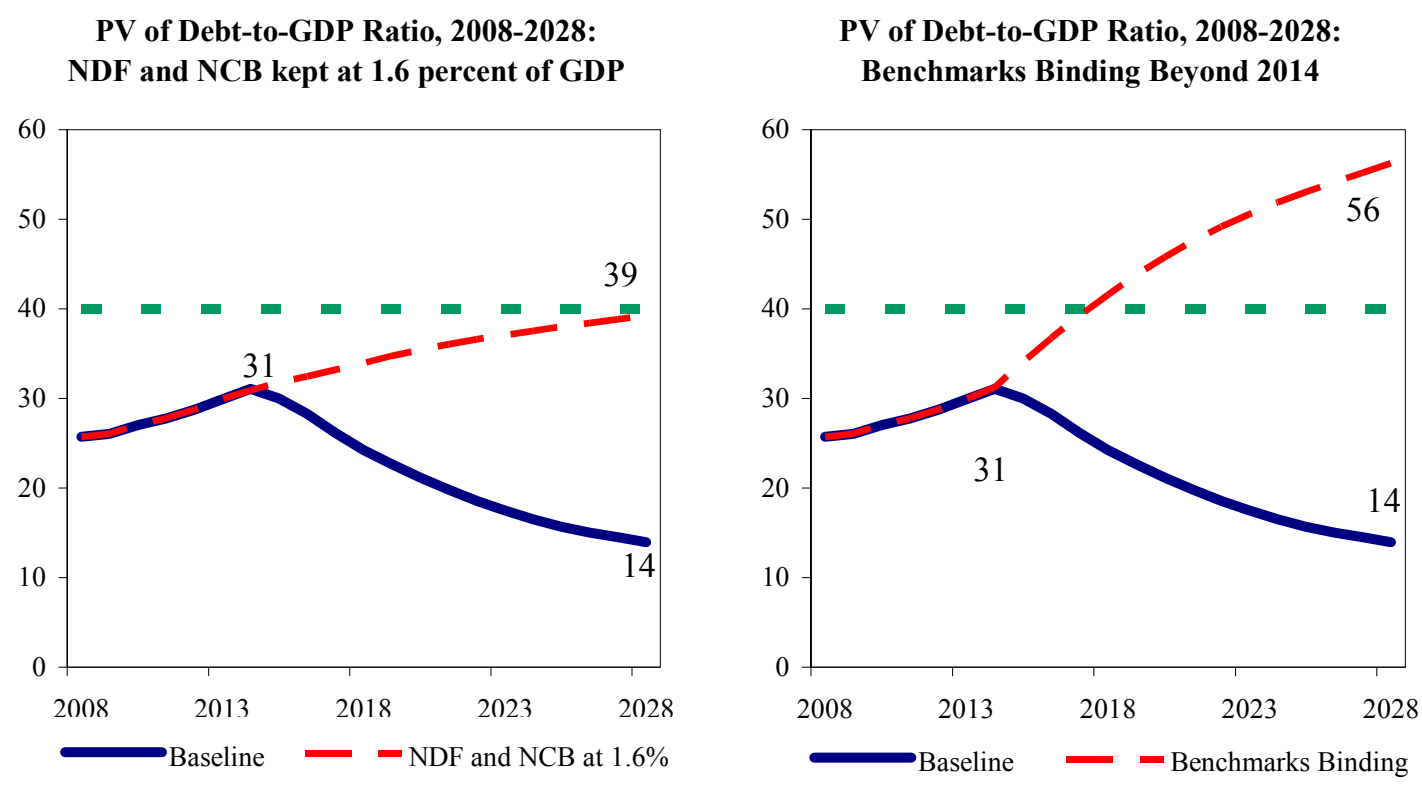

\section{The zero NDF target}

The zero NDF target, which has helped keep expenditure policy prudent in recent years, imposes a constraint on development spending in the medium term. The total nonconcessional borrowing of US\$4.4 billion in the baseline comprises external borrowing of US $\$ 1.4$ billion and domestic borrowing of US\$3.0 billion. This implies that the zero NDF target together with no external NCB would force Tanzania to cut back its much-needed development spending (or other spending) by US $\$ 3.5$ billion (Tsh 5.3 billion). ${ }^{29}$ This consolidation would imply, for example, average development spending of 8.9 percent of

\footnotetext{
${ }^{28}$ Real interest is assumed to be 5 percent, real output growth 6 percent, nominal interest rate 12 percent, and the rate of exchange rate depreciation 3 percent.

${ }^{29}$ The amount that needs to be cut back is less than the net domestic borrowing under the baseline scenario; the difference is the debt service on new borrowing.
} 
GDP instead of 10.4 percent. The zero NDF target could therefore cause problems for Tanzania in meeting the medium-term fiscal policy objectives envisioned in MKUKUTA.

\section{Boundary of fiscal space}

If Tanzania were to borrow up to the boundary of fiscal space and if all the additional borrowing were to be allocated to development spending (or any expenditure cut were to be taken out of development spending), Tanzania could afford higher development spending than the baseline assumes in the medium term and a few years beyond, but in the long run the debt service burden would be higher. Where is the boundary of the fiscal space that the diamond rule would suggest? As discussed, Tanzania could reach the debt ceiling of 40 percent by 2018 if both benchmarks (or speed bumps) become binding beyond the medium term, or by 2029 if NDF and NCB are kept at about 1.6 percent of GDP. In the latter case, development spending would average 10.4 percent of GDP over the medium term $(2009 / 10-2014 / 15)$ as in the baseline. Over the next five years $(2015 / 16-2019 / 20)$ development spending would average 10.8 percent of GDP. However, beyond 2019/20 it would have to be cut from about 10 percent of GDP eventually to $71 / 2$ percent as interest payments increase from about 3 percent of GDP to $4 \frac{1}{3}$ percent. This simulation result is sensitive to the growth assumptions discussed earlier. Without a healthy return on investment (i.e., the growth rate remains at 6 percent through the medium term), the PV of debt-to-GDP ratio would reach the ceiling by $2015 / 16$. Therefore, fiscal consolidation would need to start before 2015/16.

\section{An Alternative scenario}

The following alternative scenario incorporates additional external borrowing on nonconcessional terms; external borrowing is assumed to be 1 percent of GDP a year for the next 10 years rather than 5 (2010/11-2019/20). The terms of domestic and foreign financing are assumed to be the same. The real GDP growth rate would remain at 7.5 percent of GDP a year until 2019/20, with the same assumption on return on investment, and begin to fall to 6 percent by $2022 / 23$.

In this scenario development spending would average 10.2 percent of GDP for 11 years (2009/10-2019/20). It would be financed by NCB of US\$10.5 billion over 11 years, US\$3.7 billion of it from external sources. The additional borrowing would increase the PV of debt in 2028/29 to 31 percent of GDP instead of 14 percent (Figure 3). Note that in contrast to the baseline, debt increases faster during the post-investment period. 
Figure 3. Tanzania: Indicators of Public Debt, 2008-2028 Alternative Scenario
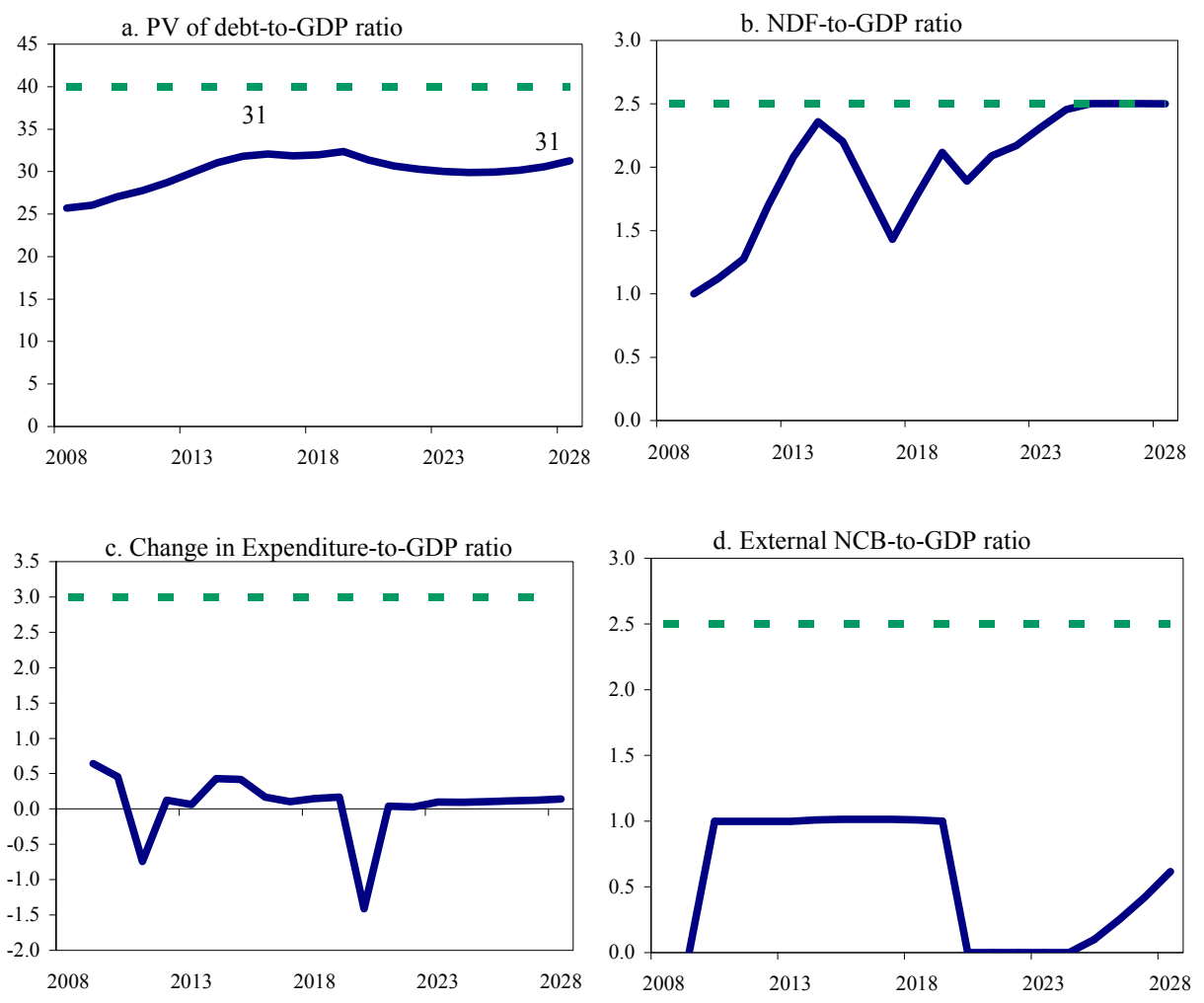

\section{Role of concessional borrowing and grants}

The debt burden of this alternative scenario can be lessened if foreign borrowing has a concessionary component. For example, if the additional external borrowing of US\$3.7 billion were evenly split between concessional and nonconcessional loans, the PV of debt in 2028/29 is 17 percent of GDP instead of 31 percent, and replicating the debt dynamics similar to the baseline becomes feasible (Figure 4). Here, interest on concessional foreign borrowing is assumed to be 1 percent (with a 7-year grace period and 20-year maturity). 
Figure 4. Tanzania: Indicators of Public Debt, 2008-2028 Role of Concessional Borrowing and Grants
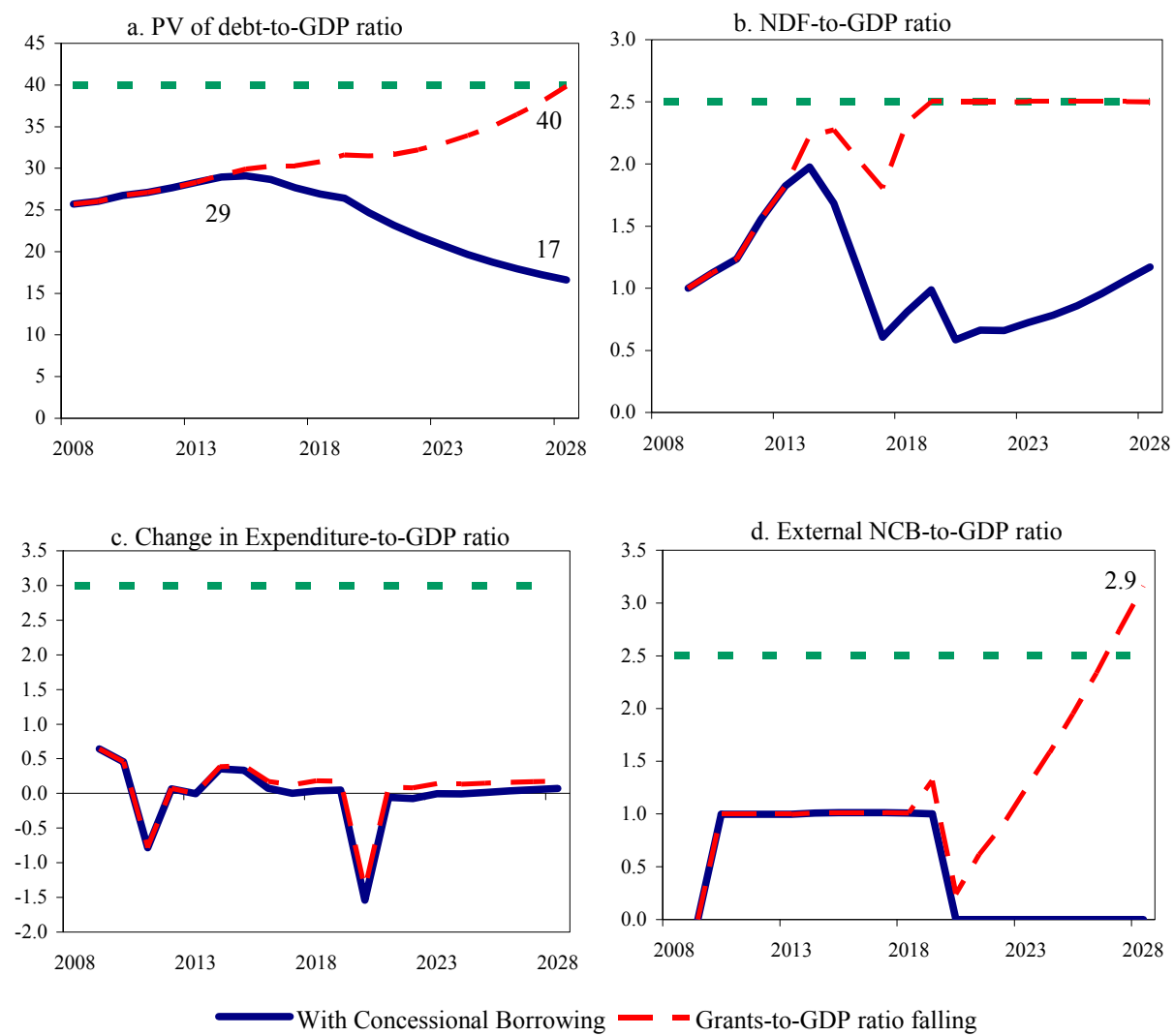

On the other hand, if the flow of grants as a share of GDP were to fall, the PV of debt-toGDP ratio would increase (indicated by dotted lines in Figure 4). Replacing grants with nonconcessional borrowing would imply that the PV of public debt would increase to 40 percent of GDP by 2028/29 if there were no fiscal adjustments during the entire projection period. These two scenarios illustrate that access to low-cost financing, including grants, is critical for debt sustainability in Tanzania.

Average Development Spending under Various Scenarios (Percent of GDP)

\begin{tabular}{lrrr}
\hline & Medium Term & \multicolumn{2}{c}{ Long Term } \\
& $2009 / 10-2014 / 15$ & $2015 / 16-2019 / 20$ & $2020 / 21-2028 / 29$ \\
\hline Baseline 1/ & 10.4 & 9.0 & 9.0 \\
Zero NDF Target & 8.9 & 9.0 & 9.0 \\
Boundary of Fiscal Space 2/ & 10.4 & 10.8 & gradually falls to 7.5 \\
Alternative Scenario 3/ & 10.4 & 10.4 & 9.0 \\
\hline
\end{tabular}

$1 /$ An increase in development spending over 5 years.

2/ NDF and NCB are kept at about 1.6 percent of GDP over the entire projection period.

$3 /$ An increase in development spending over 10 years. 


\section{Diamond Rule}

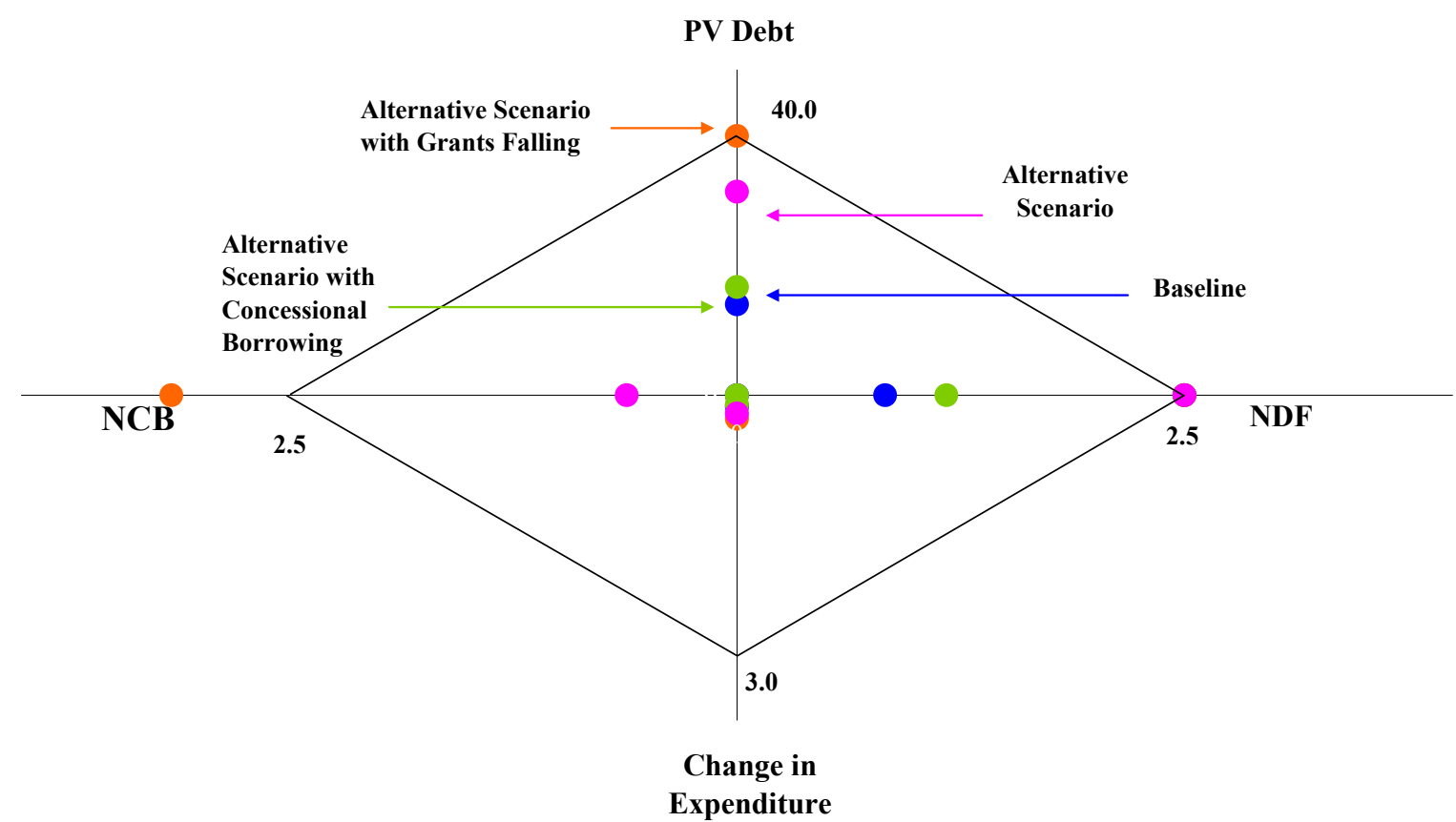

\section{Concluding Remarks}

A zero net domestic financing target has served Tanzania well in recent years, helping to keep expenditure policy prudent and to improve fiscal sustainability. However, a shift toward a rule-based MTFPF, the diamond rule, which combines a permanent hard ceiling on debt and limits on three benchmark flow variables, can provide more flexibility for countercyclical policy and help define fiscal space for infrastructure spending. An illustrative simulation shows that increasing development spending by 2 percentage points of GDP from the current level over five years, financing of which is evenly split between domestic and foreign sources, would be consistent with the diamond rule under a reasonable assumptions on growth and financing costs. However, the simulation also confirms that ensuring that public investment is growth-enhancing and access to low-cost financing are critical to keep Tanzania's debt sustainable. Exploring low-cost financing for infrastructure investment and improving expenditure policy to maximize the growth impact of investments are particularly important. 


\section{References}

Briceno-Garmendia, Cecilia, and Vivien Foster, 2007, More Fiscal Resources for Infrastructure? Evidence from East Africa, Sustainable Development Department and Africa Region (Washington: World Bank).

Corbacho, Ana, and Gerd Schwartz, 2007, "Fiscal Responsibility Laws," in Promoting Fiscal Discipline, ed. by Manmohan S. Kumar and Teresa Ter-Minassian (Washington: International Monetary Fund).

Debrun, Xavier, David Hauner, and Manmohan S. Kumar, 2007, "Discretion, Institution, and Fiscal Discipline," in Promoting Fiscal Discipline, ed. by Manmohan S. Kumar and Teresa Ter-Minassian (Washington: International Monetary Fund).

European Commission, 2006, Public Finance in the EMU (Brussels: EC).

Heller, Peter, 2005, “Understanding Fiscal Space,” IMF Policy Discussion Paper 05/04 (Washington: International Monetary Fund).

International Monetary Fund, 2003, "Public Debt in Emerging Markets: Is It Too High?" World Economic Outlook, September (Washington: International Monetary Fund).

Kopits, George, and Steven Symansky, 1998, "Fiscal Policy Rules," IMF Occasional Paper 162 (Washington: International Monetary Fund).

Ndulu, Benno J., 2006, "Infrastructure, Regional Integration and Growth in Sub-Saharan Africa: Dealing with the Disadvantages of Geography and Sovereign Fragmentation," Journal of African Economies, Vol. 15, AERC Supplement 2, pp. 212-44.

Ter-Minassian, Teresa, Richard Hughes, and Alejandro Hajdenberg, 2008, "Creating Sustainable Fiscal Space for Infrastructure: The Case of Tanzania," IMF Working Paper No. 08/256 (Washington: International Monetary Fund). 